\title{
Comparison of Aided and Unaided Thresholds and Selection Processes of Contralateral Routing of Signal Hearing Aids and Implantable Bone Conduction Devices in Patients with Asymmetric Hearing Loss
}

\author{
Yong Han Kim, Ho-Jun Lee, Mi Rye Bae, Ja Yoon Ku, Chol Ho Shin, and Hong Ju Park \\ Department of Otorhinolaryngology-Head and Neck Surgery, Asan Medical Center, University of Ulsan College of Medicine, \\ Seoul, Korea
}

좌우 비대칭형 난청 환자에서 $\mathrm{CROS}$ 보청기와 이식형 골도보청기의 선택 과정과

착용 전후 청력역치의 비교

김용한 · 이호준 · 배미례 · 구자윤 · 신철호 · 박홍주

울산대학교 의과대학 서울아산병원 이비인후-두경부외과학교실

Received April 25, 2018

Revised August 27, 2018

Accepted September 3, 2018

Address for correspondence

Hong Ju Park, MD, PhD

Department of Otorhinolaryngology-

Head and Neck Surgery,

Asan Medical Center,

University of Ulsan

College of Medicine,

88 Olympic-ro 43-gil, Songpa-gu,

Seoul 05505, Korea

Tel $+82-2-3010-3700$

Fax $+82-2-489-2773$

E-mail dzness@amc.seoul.kr
Background and Objectives We reviewed the selection processes of contralateral routing of signal (CROS) hearing aids (HAs) and bone-conduction (BC) Has, and compared aided and unaided hearing thresholds.

Subjects and Method Twenty-four patients with asymmetrical hearing loss who used BC HAs $(n=12)$ and CROS HAs $(n=12)$ were enrolled. The choice of two different HAs were compared with respect to the degree of hearing loss, the unaided hearing thresholds and functional gains. Results When the hearing thresholds of the better hearing ears were $>30 \mathrm{~dB}$ HL, most $(92 \%$, 11 of 12) chose CROS rather than BC HAs, with significant difference $(p=0.001)$. Both CROS and BC HAs groups showed significantly improved functional gains ( $46.6 \mathrm{~dB}$ and $53.4 \mathrm{~dB}$, respectively). Aided air-conduction (AC) thresholds (40.2 dB HL) in the CROS group were similar to the $\mathrm{AC}$ thresholds (43.1 dB HL) of better hearing ears. However, the hearing threshold of Aided AC thresholds (35.8 dB HL) in BC HAs group were less than the $\mathrm{BC}$ thresholds (17.3 $\mathrm{dB}$ HL) of better hearing ears by $19 \mathrm{~dB}(p<0.001)$.

Conclusion Both groups showed significantly increased functional gains. CROS HAs were preferred when hearing thresholds in better hearing ears were $>30 \mathrm{~dB}$ HL. The CROS group showed aided thresholds similar to the thresholds of better hearing ears, but the BC HAs group showed poorer aided thresholds than the thresholds of better hearing ears. For patients with asymmetric hearing loss, HAs should be selected based on the degree and types of hearing loss and the maximum output level of the selected device.

Korean J Otorhinolaryngol-Head Neck Surg 2019;62(3):157-64

Key Words Bone conduction · Contralateral routing of signal · Deafness · Hearing aids · Hearing loss $\cdot$ Single-sided.

This is an Open Access article distributed under the terms of the Creative Commons Attribution Non-Commercial License (https://creativecommons.org/licenses/by-nc/4.0) which permits unrestricted non-commercial use, distribution, and reproduction in any medium, provided the original work is properly cited. 


\section{서 론}

일반적으로 성인에서 일측성 난청은 갑자기 발생하는 경우 가 많으며, 원인이 밝혀지지 않는 경우가 많다. 양쪽 귀의 작 은 청력역치의 차이도 다자간의 대화가 많은 소음 환경에서는 문장이나 단어의 인지에 제한을 주며, 한쪽 귀의 전농의 경 우에는 보다 심각한 영향을 준다. ${ }^{1}$ 한쪽 귀의 전농이 있을 경 우 전농이 있는 쪽에서 발생하는 소리를 듣지 못하게 되는 것 뿐 아니라, 소음 하에서 언어의 인지가 어렵게 되고, 소리가 어 느 쪽에서 오는지 방향감각을 잃게 된다. ${ }^{2)}$ 이러한 한쪽의 전 농을 극복하기 위한 방법으로는 손상된 귀의 청력을 호전 시 기는 인공와우수술을 생각해 볼 수 있으며, 다른 방법으로 전 농이 있는 귀로 들어오는 소리를 보다 잘 듣는 귀 쪽으로 전달 하는 방법이 있으며, 가능한 방법으로는 contralateral routing of signal(CROS) 보청기와 이식형 골도보청기(implantable bone-conduction hearing aids)를 생각해 볼 수 있다. CROS 보청기는 전농이 있는 귀에 위치한 마이크를 통해 소리를 받 아, 그 신호를 보다 잘 듣는 반대쪽 귀에 위치한 보청기에 전 해주어 잘 듣는 귀에서 양쪽에서 오는 소리를 함께 들을 수 있게 하는 기기이다. 이식형 골도보청기는 수술을 통해 전농 이 있는 귀 뒤에 이식형 골도보청기를 위치시켜 전농이 있는 쪽의 소리에 반응을 하여 골도보청기가 진동을 함으로써 두 개골 전체가 진동을 하게 되고, 이 진동은 양쪽 와우를 동등 하게 자극하므로, 반대쪽 잘 듣는 귀에서도 전농이 있는 귀 로 들어오는 소리를 들을 수 있게 된다. ${ }^{3)} \mathrm{CROS}$ 보청기나 이 식형 골도보청기의 경우 전농이 있는 쪽에 소음이 들릴 경우 이 소음이 청력이 좋은 쪽 귀에 전달되어 청력이 좋은 귀에 서의 언어 인지를 방해할 수는 있으나, 일반적으로 전농 귀로 들어 오는 소리 자체를 들을 수 있게 하는 장점과 소음 하에 서의 언어인지의 향상과 주관적인 만족감의 호전을 보이는

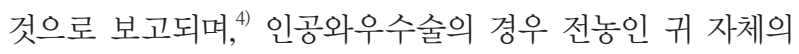
청력 호전뿐 아니라 이명의 감소와 방향성의 호전을 보이는 추가적인 장점이 보고된다. ${ }^{5-7)}$

최근, 국내에서 이식형 골도보청기는 다양한 기기가 시판 되고 있으나, 각 기기의 특징과 이러한 다양한 이식형 골도보 청기 중 환자에 따라 어떤 보청기를 선택하는 것이 좋을지에 대한 정보가 많지 않은 실정이다. ${ }^{8-11)}$ 본 연구에서는 $\mathrm{CROS}$ 보 청기와 다양한 이식형 골도보청기를 사용한 환자를 대상으 로 시술 전후에 시행한 청력역치를 분석하고, 이식형 골도보 청기와 $\mathrm{CROS}$ 보청기를 사용한 환자의 청각학적 차이를 비 교하여 각 기기에 따른 청력역치의 변화를 분석함으로써, 환 자의 난청 종류와 정도와 각각의 기기의 특성에 따라 적절한 기기의 선택과정을 알아보고 수술 후 기대되는 청력역치의 변
화를 알아보고자 한다.

\section{대상 및 방법}

\section{대 상}

2011년 5월부터 2017년 1월까지 이식형 골도보청기 수술을 받은 환자와 $\mathrm{CROS}$ 보청기를 착용한 환자를 대상으로 의무 기록과 청력검사 결과를 후향적으로 분석하였다. 양쪽 귀의 난청이 있는 양측성 선천성외이기형 소아 환자는 제외하였다. 환자는 남자 12 명, 여자 12 명으로 나이는 $56 \pm 21$ 세이었으며, $\mathrm{CROS}$ 보청기 착용군은 12 명, 이식형 골도보청기 착용군은 12 명이었다. $\mathrm{CROS}$ 보청기 착용군은 중이염 환자 2 명을 제외하 고는 모두 감각신경성 난청이었으며, 이식형 골도보청기 착용 군은 중이염 6 명, 감각신경성 난청 6 명이었다. 모든 환자에서 보청기를 착용한 귀의 청력이 반대쪽 귀의 청력보다 나쁜 비 대칭성의 청력역치를 보였으며, $\mathrm{CROS}$ 보청기 착용군은 모두 보청기 착용 귀의 청력역치가 $70 \mathrm{~dB} \mathrm{HL}$ 이상의 고도 및 심도 의 난청을 보였으며, 이식형 골도보청기 착용군은 10 명에서 고 도 및 심도의 난청을 보였으며 나머지 2명은 $61,66 \mathrm{~dB} \mathrm{HL}$ 의 중고도 난청을 보였다. 평균 추적관찰 기간은 $25.5 \pm 24$.4개월 (범위 3 112개월)이었다. 본 연구 프로토콜은 본원 임상연구 심의위원회(Institutional Review Board)의 승인을 얻었으며 (IRB No. S2018-2047-0001), 헬싱키선언(Declaration of Helsinki)을 준수하였다.

\section{이식형 골도보청기와 CROS 보청기의 선택과정}

일측성 고도 및 심도난청을 보이는 환자가 양이청을 위해 내 원할 경우, 환자에게 $\mathrm{CROS}$ 보청기[청력이 상대적으로 좋은 쪽 의 청력이 경도 또는 중등도 이상의 난청이 있을 경우 bilateral microphones with contralateral routing of signal(BiCROS) 보청기], 이식형 골도보청기, 인공와우이식술(청력이 나쁜 쪽 의 청력이 보청기의 적응증을 넘어설 정도로 나쁠 경우) 등 의 모든 옵션의 장단점에 대해 상의한다. 인공와우수술은 환 자가 미리 경험할 수 없기 때문에, 나머지 두 가지 기기를 모 두 체험할 수 있도록 기회를 제공하였다. CROS 보청기의 시 험 착용과 BAHA BP110 기기(Cochlear, Sydney, Australia)를 test-band에 부착하여 시험 착용을 한 상태로 functional gain을 측정하여 적절한 이득이 주어지고 있는지 확인하여 환자로 하여금 수술 후에 기대할 수 있는 청력재활의 정도를 미리 경험하게 한 후 환자로 하여금 적절한 기기를 선택하게 하였다.

이식형 골도보청기를 선택하는 경우, 진동자가 들어있는 골 도보청기와 두개골을 연결하는 접지대(abutment)를 고정하기 
위해 피부를 뚫는 형식(percutaneous)의 이식형 골도보청기 (BAHA 기기)와 피부에 구멍을 내지 않고 두개골에 자석(Sophono 기기)이나 금속판(BAHA Attract)을 위치시킨 후 자력 을 이용하여 두피 위에 진동자가 들어있는 골도보청기를 부 착하게 하는 형식(transcutaneous)의 골도보청기 또는 진동자 를 포함한 골도보청기를 직접 두개골 안에 이식한 후 음향처 리기를 피부 위에 부착하는 골도보청기(Bonebridge)의 장단 점을 설명한다. 청력이 좋은 귀의 골도 청력역치를 확인하여 $30 \mathrm{~dB} \mathrm{HL}$ 이내의 골도 청력역치를 보일 경우에는 모든 종류 의 이식형 골도보청기(Sophono, BAHA, Bonebridge 기기) 의 장단점을 설명 후 선택하게 하며, $30 \mathrm{~dB}$ HL보다 골도 청 력역치가 더 나쁠 경우에는 BAHA와 Bonebridge 기기의 장 단점을 설명하여 환자가 선택하게 하였다. 모든 환자는 각 의 료기기의 적응증에 합당한 환자를 대상으로 하였으며, 그렇 지 않은 경우는 기기의 사용을 추천하지 않았다.

\section{보청기 착용 전후 청력역치의 평가}

시술 전 $0.5,1,2,4 \mathrm{kHz}$ 에서 기도 및 골도 순음 청력역치를 측정하고, 보청기 착용 후 순음 청력역치는 음장(soundfield) 하에서 시행되었는데, 환자의 앞에 약 1 미터 정도의 거리에 설치된 스피커를 이용하였으며 이식형 골도보청기 착용군에 서는 반대쪽 잘 듣는 귀는 ear plug(E.A.R. Classic Plugs; Aero Industries Inc., Indianapolis, IN, USA)로 밀폐하였다. $\mathrm{CROS}$ 보청기 착용군에서는 청력이 나쁜 쪽에서 오는 소리 만을 청력이 좋은 쪽 귀로 증폭하여 자극하게 한 상태에서 음장검사를 시행하였다. 청력의 호전 정도는 보청기 착용 전 과 후의 기도 청력역치의 차이로 기능이득(functional gain)을 측정하였다. 또 다른 방법으로 보청기를 통한 청력 개선 정도 를 예측하기 위해, 이식형 골도보청기 착용군의 경우에는 수 술 전 청력이 좋은 쪽 귀의 골도 청력역치(bone-conduction threshold in good hearing ears)와 수술 후 이식형 골도보청

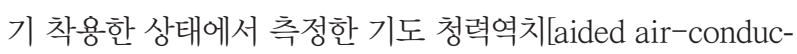
tion(AC) threshold in bad hearing ears]의 차이를 분석하 였다. $\mathrm{CROS}$ 보청기 착용군의 경우에는 청력이 좋은 쪽 귀의 기도 청력역치(AC threshold in good hearing ears)와 CROS 보청기 착용한 상태에서 측정한 기도 청력역치(aided $\mathrm{AC}$ threshold in bad hearing ears)의 차이로 계산하였다.

\section{통계 분석}

청력에 따라 보청기를 선택한 빈도의 비교는 Fisher's exact test를 이용하였다. 두 군 간의 청력역치나 기능이득(functional gain)의 비교를 위해 Mann-Whitney test를 이용하였다. 이식 형 골도보청기 착용군의 경우에서는 시술 전 청력이 좋은 쪽
귀의 골도 청력역치와 시술 후 이식형 골도보청기를 착용한 상태에서의 기도 청력역치의 차이를 Wilcoxon signed rank test를 이용하여 비교하였으며, $\mathrm{CROS}$ 보청기 착용군의 경우 에는 청력이 좋은 쪽 귀의 기도 청력역치와 $\mathrm{CROS}$ 보청기 착 용한 상태에서의 기도 청력역치의 차이를 Wilcoxon signed rank test를 이용하여 비교하였다. 검사 결과인 $p$ 값은 0.05 이하를 통계학적으로 의미 있는 것으로 해석하였다.

\section{결 과}

청력이 좋은 귀의 골도 및 기도 청력을 기준으로 $30 \mathrm{~dB} \mathrm{HL}$ 을 넘지 않는 경우를 기준으로 보청기의 선택을 비교하여 보 았다. CROS 보청기를 선택한 환자 12명 중 11명(92\%)이 30 $\mathrm{dB} \mathrm{HL}$ 이상의 기도 청력역치를 보였으며, 이식형 골도보청 기를 선택한 환자 12 명 중 1 명(8\%)이 $30 \mathrm{~dB} \mathrm{HL}$ 이상의 골도 청력역치를 보여, 유의한 차이를 보였다( $p=0.001) .20 \mathrm{~dB} \mathrm{HL}$ 을 기준으로 비교할 때에도 CROS 보청기를 선택한 환자 12 명 중 11 명(92\%)이 $20 \mathrm{~dB} H \mathrm{HL}$ 이상의 기도 청력역치를 보였 으며, 이식형 골도보청기를 선택한 환자 12 명 중 5명(42\%)이 $20 \mathrm{~dB}$ HL 이상의 골도 청력역치를 보여, 유의한 차이를 보였 다 $(p=0.03)$. 이식형 골도보청기 착용군 12 명 중 4 명의 환자는 Sophono Alpha-2 기기(Boulder, CO, USA), 4명은 percutaneous 형태의 BAHA 기기(BP 100 2명, BP 110 2명, Cochlear, Sydney, Australia), 4명은 Bonebridge 기기(MED-EL, Innsbruck, Austria)를 선택하였다.

\section{보청기 착용 전후의 청력역치 변화 및 기능이득 \\ (Functional gain)}

$\mathrm{CROS}$ 보청기 착용군의 청력이 좋은 쪽 귀의 골도 청력역 치는 $41.4 \pm 11.8 \mathrm{~dB} \mathrm{HL}$, 기도 청력역치는 $43.1 \pm 12.2 \mathrm{~dB} \mathrm{HL}$ 이었으며, 청력이 나쁜 쪽 귀의 골도 청력역치는 $85.8 \pm 16.7$ $\mathrm{dB} \mathrm{HL}$, 기도 청력역치는 $86.8 \pm 13.9 \mathrm{~dB}$ HL이었고, $\mathrm{CROS}$ 보청기를 착용한 후의 기도 청력역치는 $40.2 \pm 6.6 \mathrm{~dB} \mathrm{HL}$ 이 었다(Table 1, Fig. 1). 따라서, 기능이득(functional gain)은 $46.6 \pm 12.3 \mathrm{~dB}$ 로 $\mathrm{CROS}$ 보청기 착용 전후의 기도 청력역치는 의미 있는 차이를 보였다 $(p<0.001)$ (Fig. 1$)$.

이식형 골도보청기 착용군의 청력이 좋은 쪽 귀의 골도 청 력역치는 $17.3 \pm 12.7 \mathrm{~dB} \mathrm{HL}$, 기도 청력역치는 $30.1 \pm 23.1 \mathrm{~dB}$ $\mathrm{HL}$ 이었으며, 청력이 나쁜 쪽 귀의 골도 청력역치는 $77.7 \pm$ $27.0 \mathrm{~dB} \mathrm{HL}$, 기도 청력역치는 $89.4 \pm 17.7 \mathrm{~dB}$ HL이었고, 이식 형 골도보청기를 착용한 후의 기도 청력역치는 $35.8 \pm 10.8$ $\mathrm{dB}$ HL이었다. 따라서, 기능이득(functional gain)은 53.4 \pm 23.7 $\mathrm{dB}$ 로 이식형 골도보청기 착용 전후의 기도 청력역치는 의미 


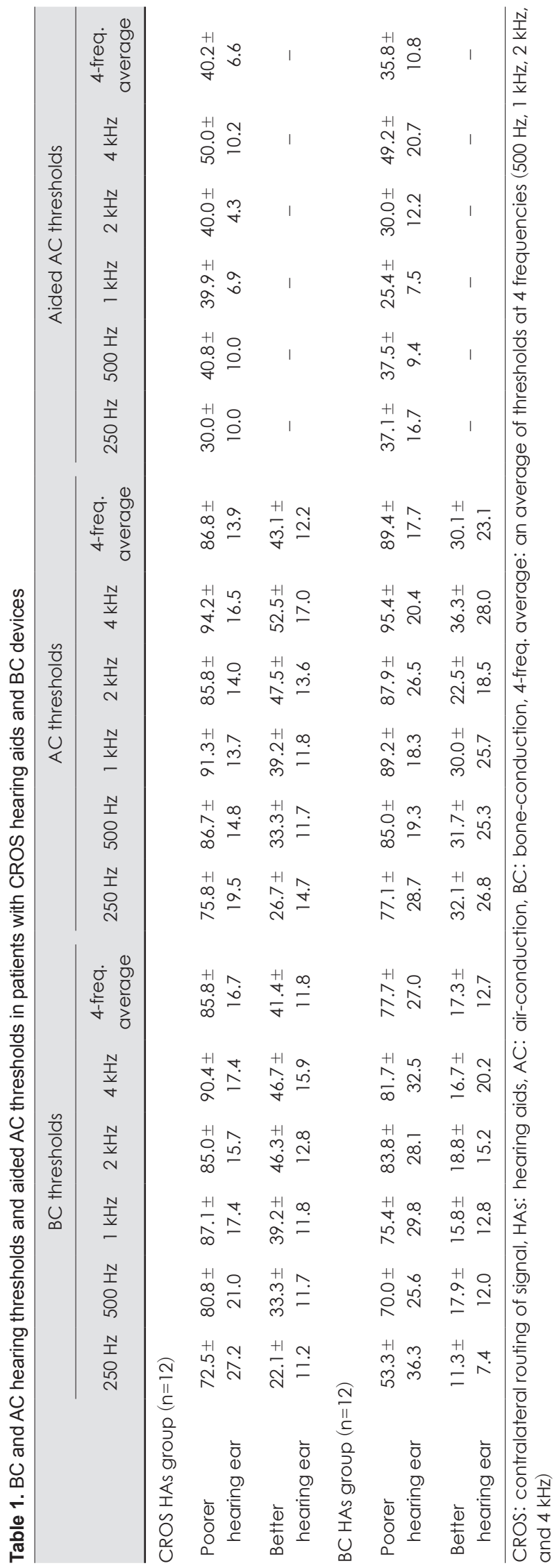

있는 차이를 보였다 $(p<0.001)$ (Fig. 1). 두 군 간의 기능이득을 비교하였을 때 차이는 관찰되지 않았다.

\section{CROS 보청기 착용군의 청력역치 예측}

$\mathrm{CROS}$ 보청기 착용군의 보청기를 착용한 청력역치는 청력 이 좋은 쪽 귀의 기도청력에 의해 결정되게 된다. 청력이 좋은 쪽 귀의 기도 청력역치(기대 청력역치)는 $43.1 \pm 12.2 \mathrm{~dB} \mathrm{HL}$ 이 었으며, $\mathrm{CROS}$ 보청기를 착용한 후의 기도 청력역치는 $40.2 \pm$ $6.6 \mathrm{~dB} \mathrm{HL}$ 로 두 청력역치 사이에 차이가 $3 \mathrm{~dB}$ 로 의미 있는 차이를 보이지 않아 청력이 좋은 쪽 귀의 기도 청력역치와 유 사한 정도로 청력역치의 개선을 보였다(Fig. 1A). 이러한 청 력역치의 차이를 각 주파수별로 관찰하였을 때에도 $2 \mathrm{kHz}$ 에 서는 더 유의미한 개선을 보였지만, 이를 제외한 대부분의 주 파수에서 청력역치의 차이를 보이지 않았다(Fig. 2A).

\section{이식형 골도보청기 착용군의 청력역치 예측}

이식형 골도보청기 착용군의 보청기를 착용한 경우는 두개 골의 진동에 의해 청력이 좋은 쪽 귀의 와우를 자극하게 되 므로, 보청기 착용 후 청력역치는 청력이 좋은 쪽 귀의 골도 청력역치(기대 청력역치)에 의해 결정되게 된다. 청력이 좋은 쪽 귀의 골도 청력역치는 $17.3 \pm 12.7 \mathrm{~dB} \mathrm{HL}$ 이었으며, 이식형 골 도보청기를 착용한 후의 기도 청력역치는 $35.8 \pm 10.8 \mathrm{~dB} \mathrm{HL}$ 로 두 청력역치 사이에 차이가 $19 \mathrm{~dB}$ 로 의미 있는 차이를 보 였다 $(p<0.001)$ (Fig. 1B). 이러한 청력역치의 차이는 각 주파 수별로 관찰하였을 때에도 모든 주파수에서 청력역치의 차이 를 관찰할 수 있었다 $(p=0.002$ at $250 \mathrm{~Hz}, p=0.002$ at $500 \mathrm{~Hz}$, $p=0.012$ at $1 \mathrm{kHz}, p=0.004$ at $2 \mathrm{kHz} ; p=0.002$ at $4 \mathrm{kHz}$ ) (Fig. 2B).

이식형 골도보청기의 종류별로 기대 청력역치와의 차이를 확인해보면, Sophono 기기, BAHA 기기, Bonebridge 기기의 청력이 좋은 쪽 귀의 골도 청력역치와 이식형 골도보청기를 착용한 후의 평균 기도 청력역치의 차이는 각각 $23,17,16 \mathrm{~dB}$ 의 순서로 감소하였다.

\section{고 찰}

기존의 보고에 의하면, 이식형 골도보청기와 CROS 보청 기 모두 청력재활 수단을 사용하지 않았을 때에 비해 청력역 치와 어음인지능력이 향상되고, 소음 환경에서도 사용하지 않 았을 때에 비해 Hearing In Noise Test(HINT) 결과 값이 호 전되며, 주관적인 만족도도 높은 장점이 보고된다. ${ }^{8-11)}$ 본 연 구에서도 $\mathrm{CROS}$ 보청기 착용하였을 때의 기능이득(functional gain)은 $46.6 \pm 12.3 \mathrm{~dB}$, 이식형 골도보청기를 착용하였을 때 

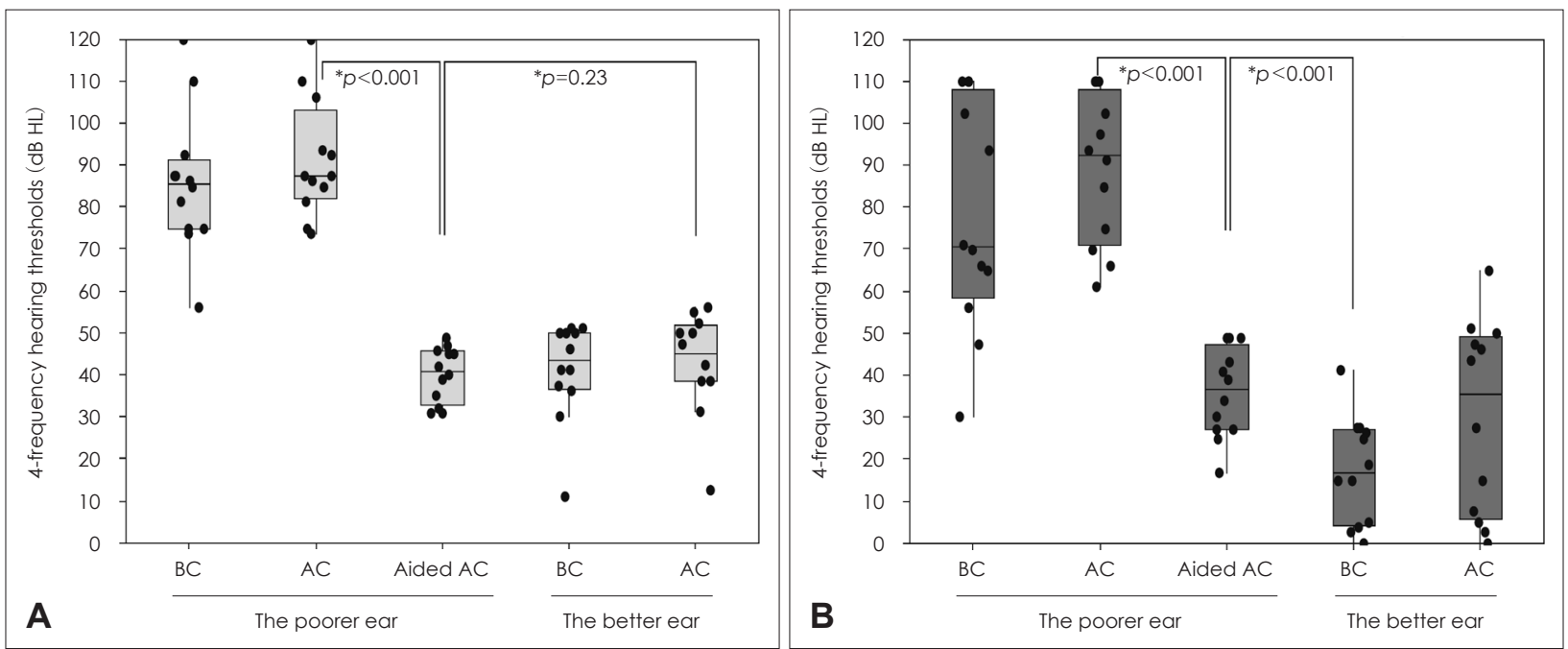

Fig. 1. Individual and boxplots for aided and unaided pure-tone average thresholds in the poorer and better hearing ears of the patients with CROS hearing aids $(A)$ and $B C$ hearing aids $(B)$. *wilcoxon signed rank test. CROS: contralateral routing of signal, $B C$ : bone-conduction, AC: air-conduction.
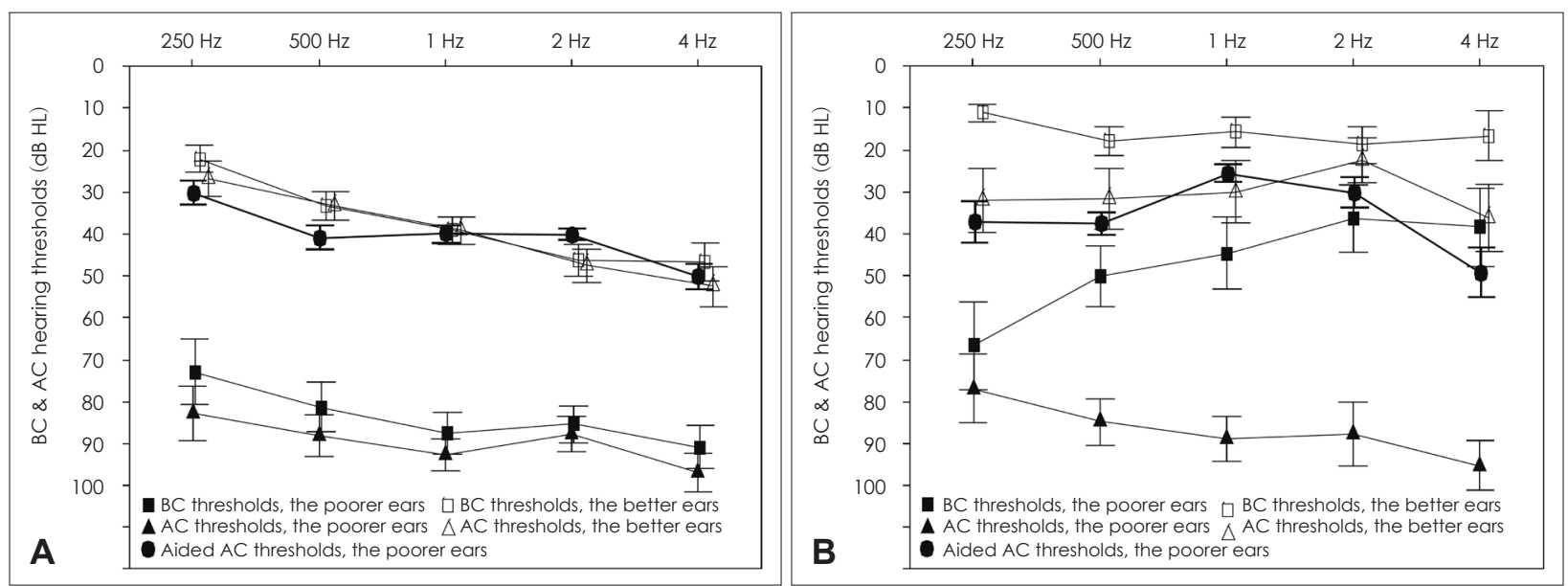

Fig. 2. Aided and unaided pure-tone thresholds (means with standard error) at each frequency in the poorer and better hearing ears of the patients with CROS hearing aids $(\mathrm{A})$ and $\mathrm{BC}$ hearing aids $(\mathrm{B})$. CROS: contralateral routing of signal, $\mathrm{BC}$ : bone-conduction, $\mathrm{AC}$ : airconduction.

의 기능이득(functional gain)은 $53.4 \pm 23.7 \mathrm{~dB}$ 로 이식형 골 도보청기와 $\mathrm{CROS}$ 보청기의 사용으로 모든 군에서 청력역치 의 호전을 보였다. 따라서, 일측성 전농 환자에서 청력재활 수단으로서 이식형 골도보청기와 $\mathrm{CROS}$ 보청기 모두 효과가 있는 것을 알 수 있다.

그러나, 일반적으로 보청기의 효과를 확인하는 데 사용되는 기능이득(functional gain)은 보청기 사용 전의 기도 청력역치 와 사용 후의 기도 청력역치의 차이를 보는 것으로 일반적으 로 청력이 나뺀 귀에 기도보청기를 사용하여 잘 들리게 하는 경우에 사용되는 측정값이다. 본 연구에서와같이 일측성 고 도 및 심도 난청 환자에서는 골도보청기로 두개골을 자극하 여도 청력이 나쁜 귀는 반응을 보이지 않으며, 보청기에 의해 증폭된 소리를 듣는 정도는 반대쪽의 청력역치에 의해 결정
되므로, 본 연구의 환자에서는 보청기의 이득을 예상하는 것 은 다른 관점에서 확인할 필요가 있다. 따라서, 보청기를 사 용함으로써 환자가 기대할 수 있는 청력역치를 착용 전에 예 상하기 위해서는 $\mathrm{CROS}$ 보청기의 경우 청력이 좋은 귀를 소리 로 자극하므로 청력이 좋은 귀의 기도 청력역치의 정도가, 이 식형 골도보청기의 경우 청력이 좋은 귀를 진동으로 자극하 므로 청력이 좋은 귀의 골도 청력역치의 정도가 중요하다. 본 연구 결과 $\mathrm{CROS}$ 보청기의 경우 청력이 좋은 귀의 기도 청력 역치와 거의 유사한 정도의 청력역치의 개선을 기대할 수 있었 고, 이식형 골도보청기의 경우 청력이 좋은 귀의 골도 청력역 치보다 약 $19 \mathrm{~dB}$ 정도 낮은 정도의 청력역치를 기대할 수 있 었다. 이식형 골도보청기의 종류에 따른 차이도 관찰되어 Sophono 기기, BAHA 기기, Bonebridge 기기의 순서대로 보 
다 좋은 청력개선을 기대할 수 있었으나, 보다 정확한 분석은 향후보다 많은 수의 환자가 모여질 경우 가능하겠다.

본 연구에서 환자의 난청의 종류와 정도, 기기의 최대출력 과 합병증 등의 여러 요소를 고려하여 보청기를 선택하였으 며, 성공적인 청각재활을 얻을 수 있었다. 이식형 보청기의 선 택에 있어서 각각의 이식형 골도보청기의 최대출력은 기기마 다 조금씩 다르기 때문에 환자의 난청의 정도에 따라 적절한 기기를 선택해야 한다. ${ }^{12-14)}$ 시뮬레이터와 실제 환자에서 각 청 력증폭기기의 최대출력을 측정한 보고에 따르면, 가장 높은 출력을 보이는 기기는 국내에서는 아직 소개되지 않은 Direct Acoustic Cochlear Stimulator(Codacs) 기기로 최대출력이 90 120 dB HL이었으며, Vibrant Soundbridge 기기가 이보 다 작은 약 $85 \mathrm{~dB}$ HL이었다. 이 두 기기의 경우에는 작동 기 전이 두개골의 진동을 유발하는 것이 아니라 수술한 쪽의 와우만를 자극하기 때문에 본 연구에서는 포함되지 않았다. 피부를 관통하는(percutaneous) 이식형 골도보청기는 종류 에 따라 일반적인 모델(BAHA Divino나 Ponto 기기)의 최대 출력은 $68 \mathrm{~dB} \mathrm{HL}$, 보다 강력한 모델(BAHA Cordelle)의 최 대출력은 $80 \mathrm{~dB}$ HL이고, 피부를 관통하지 않고 자력을 이용 하여 두피에 부착되는(transcutaneous) 이식형 골도보청기인 Bonebridge의 경우 $65 \mathrm{~dB} \mathrm{HL}$, Sophono 기기는 $56 \mathrm{~dB}$ HL 정도를 보인다. ${ }^{12-14)}$ 골도 청력역치가 높은 고도 난청에서는 보 청기의 출력이 낮은 경우에는 동적영역(dynamic range)이 작 아서 충분한 소리를 전달할 수 없게 되며, 일반적으로 적절 한 보청기의 선택은 환자의 청력역치에 비교하여 출력이 최 소한 $35 \mathrm{~dB}$ 이상 더 큰 기기를 선택하기를 추천한다. ${ }^{12)}$ 따라 서, 이를 기준으로 판단하여 각 기기의 최대출력에서 35 를 뺀 수치를 구해보면 Sophono 기기, BAHA Divino/Bonebridge 기기, 고출력인 BAHA Cordelle 기기를 사용할 수 있는 적 절한 최대 감각신경성 난청의 기준은 약 $20,35,50 \mathrm{~dB} \mathrm{HL}$ 로 보고되고, 실제로 환자에서 측정된 어음명료도의 차이도 이 러한 주장을 뒷받침한다. ${ }^{12,15)}$ 본 연구에서도 청력이 좋은 귀 의 골도 및 기도 청력을 기준으로 $30 \mathrm{~dB} \mathrm{HL}$ 을 넘을 경우 대 부분의(11명, $92 \%)$ 환자가 두 기기를 경험해 본 후 $\mathrm{CROS}$ 보 청기를 선택하여 $(p=0.001)$, 좋은 쪽 귀의 청력이 나쁠 경우 환 자가 최대출력이 강한 $\mathrm{CROS}$ 기도보청기를 선호함을 알 수 있 었다. 따라서, 각각의 보청기 최대출력에 따른 적절한 증폭의 정도 여부를 환자가 체험을 통해 확인함을 추정할 수 있다.

이러한 내용을 이해하기 쉽게 증례를 든다면, 청력이 나쁜 쪽 귀는 전농이고, 청력이 좋은 쪽 귀의 골도 청력역치가 30 $\mathrm{dB} \mathrm{HL}$, 기도 청력역치가 $70 \mathrm{~dB}$ HL로 일반적인 기도보청기 를 사용하고 있는 환자가 전농인 쪽으로 오는 소리를 듣고자 내원했다고 가정하자. 일차적으로 수술을 통해 청력이 좋은
귀의 $40 \mathrm{~dB}$ 의 기도골도차를 줄이고, 전농인 귀에 인공와우 수술을 하는 선택도 있겠다. 그러나, 여러 가지 이유로 환자가 잘 듣는 귀의 수술을 원하지 않거나 불가능하다면, $\mathrm{BiCROS}$ 보청기를 선택하거나 현재 사용하는 기도보청기는 그대로 사용하면서 전농인 귀에 이식형 골도보청기를 수술하는 선 택이 가능하다. 기도 청력역치가 $70 \mathrm{~dB}$ HL이므로 최대출력이 $120 \mathrm{~dB}$ HL인 일반적인 기도보청기(최대출력이 $120 \mathrm{~dB} \mathrm{HL}$ ) 를 사용한다면, 보청기를 사용할 경우의 동적영역(dynamic range)이 50(=120-70) dB로 작기는 하지만 청력재활에는 충 분한 도움이 될 수 있다. 이식형 골도보청기를 선택할 경우 Sophono 기기의 동적영역(dynamic range)은 $26 \mathrm{~dB}$, Bonebridge의 경우 $35 \mathrm{~dB}$, BAHA Divino는 $38 \mathrm{~dB}$, 보다 강력한 모델인 BAHA Cordelle의 경우 $50 \mathrm{~dB}$ 정도이다. 따라서, 일 반적인 기도보청기는 BAHA Cordelle 기기의 동적영역과 유 사한 결과를 보일 것으로 추정된다.

위 환자의 골도 청력역치를 기준으로 평가한다면 Sophono 는 출력이 부족하여 좋은 대안은 아니며, 동적영역(dynamic range)이 $35 \mathrm{~dB}$ 를 넘게 되는 Bonebridge나 BAHA Divino를 선택할 경우 현시점에서는 충분한 출력을 낼 수도 있으나 장 기적으로 청력이 서서히 감소할 것을 고려하여 수년 후에 보 다 강력한 BAHA Cordelle로 교체를 할 필요성이 있다고 환 자에게 상담을 할 수 있겠다. 물론, 처음부터 BAHA Cordelle 을 사용할 수 있으나 크기가 상대적으로 커서 청력이 변화하 는 정도에 맞추어서 향후에 바꾸는 방법으로 청각재활을 하 는 것이 좋은 방법으로 생각된다. 정리를 하면, 이 환자의 경 우에는 청력역치의 관점에서 보면 $\mathrm{BiCROS}$ 보청기와 $\mathrm{BAHA}$ Divino 및 이보다 출력이 강력한 이식형 골도보청기 모두 선 택을 할 수 있고, 환자에게 각 기기의 장단점을 잘 설명하고 실제로 이를 사용하여 보고 환자가 결정할 수 있도록 하는 것 이 가장 좋은 방법으로 생각된다. 이식형 골도보청기의 경우 headband를 이용할 경우 수술 전에 사용하더라도 수술 후 예 상되는 청력역치 결과를 비교해 볼 때 유사한 효과를 얻을 수 있어 이를 임상적으로 사용할 수 있다. ${ }^{16)}$ 귀에 걸지 않고 귀 뒤 쪽에 고정할 수 있는 이식형 골도보청기의 경우 환자에 따라 서는 착용감에 이점을 느낄 수도 있으나, ${ }^{17)}$ 피부에 구멍을 딿 고 뼈에 고정하여 진동자와 연결하는 접지대(abutment)를 사용하기 때문에 접지대 주변에서 피부와 연부조직의 염증이 발생하는 부작용의 가능성을 환자가 알고 있어야 한다. ${ }^{18)}$

이식형 골도보청기나 $\mathrm{CROS}$ 보청기를 비교한 보고에 의하 면 소음 하 인지능력이나 삶의 질 호전 정도는 유사한 것으로 보고된다. ${ }^{19)}$ 이식형 골도보청기 수술을 받은 일측성 난청 환 자 8명을 약 2주간 CROS 보청기를 사용하게 하여 두 보청기 의 차이를 비교한 소규모 연구에 의하면 환자의 만족도에는 
큰 차이를 보이지 않는 것으로 보고되었으며, 4 명은 소리의 질이 $\mathrm{CROS}$ 보청기가 더 좋다고 판단하였고, 3 명의 환자는 착용하기에는 이식형 골도보청기가 더 편리하다고 판단하였 다. ${ }^{17)}$ 이는 동적영역(dynamic range)의 좁을 경우 소리가 왜 곡되기 때문에 좋은 쪽 귀의 청력역치가 나쁜 환자에서는 동 적영역이 큰 $\mathrm{CROS}$ 보청기가 상대적으로 유리할 수 있으리 라 생각되며, 이식형 보청기는 귀에 걸지 않아 착용감이 좋 은 장점이 있고, $\mathrm{CROS}$ 보청기는 수술을 하지 않아도 되는 장점이 있다.

추가적으로 고려할 점은, 본 연구의 결과에서도 확인할 수 있는 것처럼 기도보청기를 사용할 경우 목표점인 청력이 좋 은 쪽 귀의 기도 청력역치와 유사한 정도의 aided 청력역치를 얻을 수 있으나, 이식형 골도보청기를 사용할 경우 기대할 수 있는 aided 청력역치는 청력이 좋은 귀의 골도 청력역치보다 약 $15 \sim 20 \mathrm{~dB}$ 높게 된다. 따라서, 보청기를 착용 후 측정되는 기도 청력역치가 일반적으로 사회생활을 하는데 불편함을 가지지 않는 청력역치인 $40 \mathrm{~dB}$ HL보다 낮을 수 있는지에 대 한 예측도 필요할 것으로 생각된다.

참고로, 본 연구에서는 양측 선천성 외이도폐쇄증 소아 환 자를 제외한 주로 어른 환자만을 대상으로 하여 한 쪽 귀의 청력이 나쁜 환자가 대부분이었다. 선천성 외이도폐쇄증 환 자처럼 양쪽의 골도 청력이 정상이나 해부학적 구조로 수술 을 통한 청력개선이 기대하기 어려운 환자의 경우, 나이가 들 때까지 청력이 $20 \mathrm{~dB} \mathrm{HL}$ 이상으로 나빠질 가능성이 적기 때 문에 피부에 구멍을 뜷지 않고 자석판을 두개골에 고정하여 외부에 진동자를 위치시켜 피부 문제가 거의 없는 Sophono 기기도 좋은 대안이 될 수 있다. ${ }^{20)}$ 이러한 Sophono 기기는 두 개골에 직접 연결되어 두개골을 진동시키는 $\mathrm{BAHA}$ 기기와 달 리 피부와 연부조직의 진동을 유발하여 두개골을 진동하므 로 약 $15 \mathrm{~dB}$ 의 추가적인 출력 손실을 보인다. ${ }^{21,22)}$

결론적으로 본 연구를 통해 일측성 심한 난청이 있는 환 자에서 $\mathrm{CROS}$ 보청기와 이식형 골도보청기를 통해 청력역치 의 의미 있는 호전을 얻어 청각 재활에 도움을 줄 수 있음을 알 수 있었다. 또한, 본 연구를 통해 환자의 난청의 종류 및 정도에 따라 적절한 청각재활 기기의 선택에 필요한 다양한 고려 사항을 알아보았으며, 실제로 특정 기기를 선택 후에 어 느 정도의 청력역치를 기대할 수 있을지에 대해서도 알아보 았다. 이 연구의 결과가 임상적으로 적절한 청각재활 기기를 선택하는 일측성 고도 및 심도 난청 환자와 상담할 때 참고 자료로 사용될 수 있기를 기대한다.

\section{REFERENCES}

1) Noble W, Gatehouse S. Interaural asymmetry of hearing loss, Speech,
Spatial and Qualities of Hearing Scale (SSQ) disabilities, and handicap. Int J Audiol 2004;43(2):100-14.

2) McLeod B, Upfold L, Taylor A. Self reported hearing difficulties following excision of vestibular schwannoma. Int J Audiol 2008; 47(7):420-30

3) Niparko JK, Cox KM, Lustig LR. Comparison of the bone anchored hearing aid implantable hearing device with contralateral routing of offside signal amplification in the rehabilitation of unilateral deafness. Otol Neurotol 2003;24(1):73-8

4) Baguley DM, Bird J, Humphriss RL, Prevost AT. The evidence base for the application of contralateral bone anchored hearing aids in acquired unilateral sensorineural hearing loss in adults. Clin Otolaryngol 2006;31(1):6-14.

5) Vermeire K, Van de Heyning P. Binaural hearing after cochlear implantation in subjects with unilateral sensorineural deafness and tinnitus. Audiol Neurootol 2009;14(3):163-71.

6) van Zon A, Peters JP, Stegeman I, Smit AL, Grolman W. Cochlear implantation for patients with single-sided deafness or asymmetrical hearing loss: a systematic review of the evidence. Otol Neurotol 2015; 36(2):209-19.

7) Kitterick PT, Smith SN, Lucas L. Hearing instruments for unilateral severe-to-profound sensorineural hearing loss in adults: a systematic review and meta-analysis. Ear Hear 2016;37(5):495-507.

8) Han KH, Kim H, Jang JH, Yoo JC, Kim YH, Lee JH, et al. Hearing rehabilitation with bone anchored hearing aid: experience in 14 patients. Korean J Otorhinolaryngol-Head Neck Surg 2010;53(12): $755-60$

9) Park MN, Yoo SY, Chun YM, Moon IS, Kim SH. Hearing rehabilitation of single-sided deafness: benefit and selection criteria of bone anchored hearing aid and contralateral routing of signal hearing aid. Korean J Otorhinolaryngol-Head Neck Surg 2013;56(6):339-45.

10) Rhee J, Chung J, Kim SH, Seo MW, Koo JW, Lee JH, et al. Subjective and audiologic results of bone anchored hearing aids (BAHA). Korean J Otorhinolaryngol-Head Neck Surg 2013;56(7):418-24.

11) Kim S, Han W. Current developments and challenge of implantable bone conduction hearing aids. Korean J Otorhinolaryngol-Head Neck Surg 2018;61(2):67-75.

12) Zwartenkot JW, Snik AF, Mylanus EA, Mulder JJ. Amplification options for patients with mixed hearing loss. Otol Neurotol 2014; 35(2):221-6.

13) Mertens G, Desmet J, Snik AF, Van de Heyning P. An experimental objective method to determine maximum output and dynamic range of an active bone conduction implant: the Bonebridge. Otol Neurotol 2014;35(7):1126-30.

14) Hol MK, Nelissen RC, Agterberg MJ, Cremers CW, Snik AF. Comparison between a new implantable transcutaneous bone conductor and percutaneous bone-conduction hearing implant. Otol Neurotol 2013;34(6):1071-5.

15) Mojallal H, Schwab B, Hinze AL, Giere T, Lenarz T. Retrospective audiological analysis of bone conduction versus round window vibratory stimulation in patients with mixed hearing loss. Int $\mathrm{J}$ Audiol 2015;54(6):391-400.

16) Park MJ, Lee JR, Yang CJ, Yoo MH, Jin IS, Choi CH, et al. Amplification of transcutaneous and percutaneous bone-conduction devices with a test-band in an induced model of conductive hearing loss. Int $\mathrm{J}$ Audiol 2016;55(11):653-7.

17) Finbow J, Bance M, Aiken S, Gulliver M, Verge J, Caissie R. A comparison between wireless CROS and bone-anchored hearing devices for single-sided deafness: a pilot study. Otol Neurotol 2015; 36(5):819-25.

18) Snik AF, Mylanus EA, Proops DW, Wolfaardt JF, Hodgetts WE, Somers T, et al. Consensus statements on the BAHA system: where do we stand at present? Ann Otol Rhinol Laryngol Suppl 2005;195: $2-12$. 
19) Leterme G, Bernardeschi D, Bensemman A, Coudert C, Portal JJ, Ferrary E, et al. Contralateral routing of signal hearing aid versus transcutaneous bone conduction in single-sided deafness. Audiol Neurootol 2015;20(4):251-60.

20) Siegert R, Kanderske J. A new semi-implantable transcutaneous bone conduction device: clinical, surgical, and audiologic outcomes in patients with congenital ear canal atresia. Otol Neurotol 2013;34
(5):927-34.

21) Håkansson B, Tjellström A, Rosenhall U. Hearing thresholds with direct bone conduction versus conventional bone conduction. Scand Audiol 1984;13(1):3-13.

22) Shin JW, Kim SH, Choi JY, Park HJ, Lee SC, Choi JS, et al. Surgical and audiologic comparison between Sophono and bone-anchored hearing aids implantation. Clin Exp Otorhinolaryngol 2016;9(1):21-6. 